\title{
Thinking in Archipelagic Terms: An Interview with John Brannigan
}

John Brannigan ${ }^{\mathrm{i}}$

Interviewers:

Marcela Santos Brigida ${ }^{\text {ii }}$

Thayane Verçosa ${ }^{\text {iii }}$

Gabriela Ribeiro Nunes ${ }^{\text {iv }}$

John Brannigan, Professor at the School of English, Drama and Film at University College Dublin, is the author of books such as New Historicism and Cultural Materialism (1998), Race in Modern Irish Literature and Culture (2009), and Archipelagic Modernism: Literature in the Irish and British Isles, 1890-1970 (2014), and a leading name in his field. He is also a voice I am glad to have the opportunity to introduce to many of my peers in this piece. As a publication to which young researchers have the chance to submit their papers for the first time, and one that is edited by graduate students, Palimpsesto is, after all, a journal that circulates widely among our colleagues. As the time we have shared as general editors of Palimpsesto comes to an end with the publication of this issue, I believe Gabriela Ribeiro Nunes

\footnotetext{
${ }^{\mathrm{i}}$ John Brannigan is Professor at the School of English, Drama and Film at University College Dublin. He has research interests in the twentieth-century literatures of Ireland, England, Scotland, and Wales, with a particular focus on the relationships between literature and social and cultural identities. His first book, New Historicism and Cultural Materialism (1998), was a study of the leading historicist methodologies in late twentieth-century literary criticism. He has since published two books on the postwar history of English literature $(2002,2003)$, leading book-length studies of working-class authors Brendan Behan (2002) and Pat Barker (2005), and the first book to investigate twentieth-century Irish literature and culture using critical race theories, Race in Modern Irish Literature and Culture (2009). His most recent book, Archipelagic Modernism: Literature in the Irish and British Isles, 1890-1970 (2014), explores new ways of understanding the relationship between literature, place and environment in 20th-century Irish and British writing. He was editor of the international peer-reviewed journal, Irish University Review, from 2010 to 2016.

ii $\mathrm{PhD}$ Student in Literary Studies at Universidade do Estado do Rio de Janeiro (UERJ). CNPq Scholar. Digital content creator at Literatura Inglesa Brasil: https://instagram.com/literaturainglesabr https://orcid.org/0000-0002-0951-1603 | marcela@ literaturainglesa.com.br

iii PhD Student in Literary Studies at UERJ. CAPES Scholar. thayanevercosa@ hotmail.com

${ }^{\text {iv }} \mathrm{PhD}$ Student in Literary Theory at UERJ. j15c17g11@ hotmail.com
} 
and I would like to leave the journal with a note that reminds all of us that it is possible to produce and to enable serious academic work under a welcoming, warm atmosphere. Professor Brannigan was truly kind in accepting our invitation for an email interview. As a researcher of Irish Literature, it is a joy to thematise it in an interview in this journal for the first time since its first publication. It is a demonstration of the many avenues we can still navigate here as students in dialogue with experienced researchers whose work we admire. This, I think, is a reason to celebrate.

In the introduction to Archipelagic Modernism: Literature in the Irish and British Isles, 1890-1970 (2015), Brannigan refers to After London (1885), a novel in which Richard Jefferies 'imagined a future in which the geography of England has been dramatically altered by an environmental catastrophe' in which 'rising sea levels and the effects of human-made structures on water-courses combine to flood central and southern parts of England' (BRANNIGAN, 2015, Loc 82). The author, Brannigan observes, does not add a utopian tone to the 'archipelagic England which takes the place of its drowned antecedent' (BRANNIGAN, 2015, Loc 99). Here, there is no 'ideal society rising to flourish in the wake of the old, just a rather familiar anarchic and violent past returning to haunt an English people who could now only dimly recall having been at the centre of a global empire, and the engine of industrial progress' (BRANNIGAN, 2015, Loc 105). To William Morris, however, 'After London suggested the possibility of beginning again, of resetting the terms upon which an English society might be founded, and of how it might relate to its neighbours.' (BRANNIGAN, 2015, Loc 105). Throughout the text, Brannigan introduces the reader to the book's approach of archipelagic analysis of political identities - as well as of the relationships between the countries that occupy the islands of the Irish and British archipelago. I would argue that Archipelagic Modernism is a necessary read for anyone interested not only in modernist literature produced in Ireland, Scotland, Wales, and England, but also for those who see the need to reassess the political charges and dynamics that cut through those literatures as well.

One year into a pandemic that has impacted the way most - if not all - of us go about our lives, besides causing unfathomable collective trauma (as I write this, a notification alerts me to the fact that today Brazil registered 4.195 deaths related do 
Covid-19 $19^{1}$, many of us have turned to literature in the search for ways to cope. In our interview, Professor Brannigan pointed out that 'every pandemic has either caused or threatened to cause changes to society and culture, and so every pandemic necessitates the imagination of alternatives'. As I proudly share this piece with Palimpsesto's readers, I invite each of you to do just that. I hope that, a year from now, we will be able to meet each other safely again, and somehow look back at what happened with a critical eye, but with an already different perspective. I am deeply thankful to Professor John Brannigan for accepting our invitation and for sharing his brilliant work and words with us.

Marcela Santos Brigida

\section{PALIMPSESTO}

1) Discussing the 'grievous distance between Irish culture and the major international and political events of the wartime period' (p. 4) in the Introduction to Irish Literature in Transition, 1940-1980 (2020), Eve Patten argues that, 'from a literary perspective, mid-century Ireland often confounds the rhetoric of isolation and registers instead the impact of proximity and connection, a theme extending into the post-war decades and across diverse cultural communities' (2020, p. 5). Throughout Brexit negotiations, British Prime Ministers in charge of talks with the European Union were often accused of a disregard towards Ireland and the Good Friday Agreement (MCKENZIE, MORRIS, 2020; BEHR, 2020). Ironically, the limitations imposed by Brexit on the British themselves while abroad in Europe have led to a surge in the number of UK citizens applying for Irish visas (O'CARROLL, 2020). In that sense, this practical reclaiming of an Irish identity might take up several meanings. That tension already appears in some contemporary Irish fiction. In Naoise Dolan's Exciting Times (2020), an English banker named Ralph had 'voted for Brexit to have tighter borders, and was applying for an Irish passport to avoid being stopped at them' (p. 31). Do you believe we can expect to see more of this paradox between political isolation and a complicated instrumentalisation of identity in Irish fiction?

\section{JOHN BRANNIGAN}

This is a very interesting and productive question, especially the connection you make to the mid-century period. The political isolation of Ireland during the middle of the twentieth century was in part a reaction against being part of the British 
Empire. Neutrality during the Second World War was a very important, if controversial, way of Ireland continuing to assert its independence and selfsufficiency. For some writers who were critical of, or ambivalent about Irish neutrality, such as Louis MacNeice or Dorothy Macardle, the fight against Nazism was a call for an internationalist, humanitarian alliance, and in that context Irish neutrality seemed to be a kind of withdrawal from moral responsibility. MacNeice referred to it in his poem on Irish neutrality as 'The neutral island in the heart of man', and blamed this coldness on a fantasy of insularity, that islands can cut themselves off from the world. For all that mid-century Ireland can be seen as politically isolated, however, I think Eve Patten is right to argue that the literature of the period tells a different story. If one thinks of Finnegans Wake, published in 1939, Beckett in France throughout the war, the work of Kate O'Brien and Dorothy Macardle, and in the aftermath of the war, the continued influence of European literature can be seen in Envoy magazine, in Brendan Behan's friendship with Camus in Paris, and Sean O'Faolain's social gatherings at which he would discuss European literature with young writers. That cultural Europhilia was evident in Irish literature perhaps before it became evident politically. Ireland joined the European Community at the same time as Britain, in 1972, and in many ways it helped to normalise and stabilise political relations between the two countries, and should certainly be regarded as the foundation upon which the Good Friday Agreement was made in 1998. Brexit is something of a puzzle to many Irish people, I am sure, but in Ireland we are used to seeing the evidence of economic and cultural benefits from European Union membership. Every new road and tourist amenity comes with a sign with the EU flag on it, denoting the financial contribution made from EU funds to the project. It is harder to see evidence of such benefits in the prosperous south of England, and it is certainly a very Anglocentric view of the world which informed and fuelled Brexit. One implication of your question, I think, is that Brexit has reversed the position of Ireland and Britain from the Second World War, with Britain now choosing to isolate itself from Europe, culturally and politically. The problem with this, from an Irish cultural perspective, is that we know from our history that this is neither desirable nor possible. The rhetoric of Brexit tends always to simplify relations which are historically and inevitably complex, never more so than with Anglo-Irish relations. 
Hence, we are seeing these apparently odd phenomena emerging, of committed unionists seeking Irish passports, of a Brexit that was supposed to be about British sovereignty weakening trade and movement within the UK, and of British fishing communities - supposedly one of the motivating factors for Brexit - being the first to suffer its consequences. In my own work, I've tended to see these relations in archipelagic terms, that the islands and regions of Ireland and Britain are interlinked culturally in ways which are far more complex than national frameworks would suggest. Brexit was founded, as I've said, on a strongly Anglocentric view, and it is against this view that I think we will see the literature of the Irish and British archipelago chafing and pushing.

\section{PALIMPSESTO}

2) You open your chapter on Seán O'Casey and Brendan Behan in A History of Irish Working-Class Writing (2017) by citing Thomas Docherty's argument in Aesthetic Democracy that 'aesthetics and democracy are essentially concerned with the same fundamental question: "how does change happen, and how do we get from one state of affairs to another?"' (BRANNIGAN, 2017, p. 289). Further, you also state that 'art is potentially changed by every work of art; democracy is potentially changed by every democratic action' (BRANNIGAN, 2017, p. 289). Accepting that 'such acts of transformation are "episodic and rare", and are "grounded in hope and expectation rather than in principle" (BRANNIGAN, 2017, p. 289), it is undeniable that the pandemic has been a devastating source of change in a world-scale that has more ramifications than we have yet realised. However, do you believe that the political and social awareness it has raised in many - regarding questions ranging from healthcare to funding for the arts - will have a lasting effect?

\section{JOHN BRANNIGAN}

Every pandemic has either caused or threatened to cause changes to society and culture, and so every pandemic necessitates the imagination of alternatives, usually of course dystopian alternatives. Pandemics require us to consider fictional possibilities. Climate crises do the same - what will the world look like with sea level rise, or with permanent smog, or with the extinction of key species? And, of course, one can say that we have been imagining the social changes brought about by pandemics long before our current pandemic. Throughout this pandemic, numerous politicians have 
talked about following the science, but in some ways the science has also been following a cultural narrative. In books and films and art we had already become used to the narrative and imagery of masks, social distancing, overwhelmed hospitals and mortuaries, the emptying of the streets, the panic buying in supermarkets, the hunt for a vaccine or cure, and so on. At the beginning of the coronavirus pandemic, for example, many people began to turn to reading Camus's The Plague, or Love in the Time of Cholera ${ }^{3}$, or The Andromeda Strain ${ }^{4}$. We have been imagining pandemics for a long time, and our imagination of them is a manifestation of concern about the future, and how the narrative of our contemporary forms of society, culture and economy plays out. The influenza pandemic of 1918 was also pre-imagined in books like Jack London's The Scarlet Plague, and it also made its mark on the literature of the period, on Eliot's The Waste Land and Woolf's Mrs Dalloway and To The Lighthouse, for example. The cultural impact, arguably, was immense, and some argue that the Jazz Age of the 1920s and early 1930s can be attributed to the reaction to this pandemic. So, we have cultural models that can help us to understand pandemics and their impacts. This is not to say, however, that the impact of the pandemic itself has not been shocking, and has the potential to cause change. It is possible that the wider awareness of social inequalities, of the underfunding of healthcare, welfare, education and the arts, and the role of the state in biopolitics, may drive demand for change. At the worst points of the pandemic, we have recognized that the people we have come to know as 'essential workers' happen also to be the lowest-paid workers. There was a similar moment, of course, during the financial crash of 2008, when people began to see this as a crisis for capitalism. Fredric Jameson has alerted us to the ways in which imagining the end of the world - which is certainly how many pandemic fictions unfold - may often be a proxy for imagining the end of capitalism. But what we hear now more often with the rolling out of the vaccine programmes is the clamour for a return to normality, and it would be difficult to predict lasting positive change in politics and society in that context.

\section{PALIMPSESTO}


3) In the 2020 US election cycle, Joe Biden often quoted lines from Seamus Heaney's The Cure at Troy (1991). Throughout his political career, he also quoted from - and pronounced himself a fan of - Yeats. In a 2013 remark made popular since his inauguration, Biden said: 'My colleagues always kid me about quoting Irish poets all the time. They think I do it because I'm Irish, I do it because they're the best poets' (BIDEN, 2013). While most have seen this connection with Irish literature as a positive influence on American politics, some joked on Twitter about how Biden's references appear to include only men ${ }^{5}$. Which Irish women poets would you recommend to expand the reading habits of those interested in Irish poetry?

\section{JOHN BRANNIGAN}

Where to start? First of all, I must be honest, and say that when I hear Biden quoting Heaney and Yeats, I feel a small glow of pleasure. It feels like such a relief after the last four years of incomprehensible and offensive tweets. But, of course, Biden is not the first President to do so, and Obama and Clinton often quoted from the same poets, mainly in relation to the peace process in Northern Ireland. To be more cynical, of course, when politicians quote poetry, there are usually very calculated political reasons for doing so, that it makes them appear more literate and educated, that it appeals to certain constituencies of voters, or raises political rhetoric from the mundane matters of economic management to the realm of social and cultural aspiration. Geraldine Higgins wrote a great article about this ${ }^{6}$, especially about how politicians quoted Yeats during the peace process, and she argued that Yeats had become the favoured poet for politicians to quote. Of course, there are many Irish poets who are women and who are as eminent, as widely read, and as quotable as either Yeats or Heaney - Eavan Boland, Sinead Morrissey, Nuala Ní Dhomhnaill, Eiléan Ní Chuilleanáin, Paula Meehan, Moya Cannon, Mary O’Malley, Medbh McGuckian, Vona Groarke, just for a start. That they are generally not quoted in political speeches, at least with nothing like the same frequency as we find Yeats and Heaney quoted, is an indication of the narrow terms on which such political benediction of poetry takes place. If I was to hazard a guess about the reasons for the narrow, male nature of this canon of quotable poets, I think it is to do with a lurking assumption that male poets are public voices, who speak the conscience of the tribe, whereas female poets are assumed to be private, individual voices. And thus, such male poets are understood to carry a kind of cultural authority which can be borrowed 
and spent in the public domain of politics. Perhaps another reason is that Yeats and Heaney have, rightly or wrongly, often been associated with a national narrative, with a singular allegiance, and here I would think of Edna Longley's argument from The Living Stream $^{7}$ that there is an alternative, feminist tendency to inhabit multiple relations and allegiances simultaneously, and to connect them.

\section{PALIMPSESTO}

4) In the Foreword to Re: Joyce: Text. Culture. Politics (1998), you, Julian Wolfreys, and Geoff Ward argue that it is fitting that "the "Joyce tour" of bronze paving inscriptions now forms part of the physical landscape of the city, as if literalizing the imprint of Joyce on Irish culture' and that 'that such imprints are primarily tourist attractions, projected outside the nation from within' (p. xiv-xv). This is, you explain, 'true of the complex relationship between Joyce and Irish culture' (p. xiv). In your chapter in that same book, 'Joyce Will Attend: The Joyce Tour of Postwar Literature', you argue that:

\footnotetext{
Joyce proliferates in spectres throughout postwar literature, but not, however, in order to preserve an essential Joyce, a familiar Joyce. Rather, spectres of Joyce attend today in order to pay homage to the absent Other, to the un-Joyce, and more importantly to invite us constantly to displace the achievement of knowing Joyce. Joyce is the involuntary text, the startling spectral Other, circulating through postwar literature. Joyce will attend, but always already as Other, as difference. (p. 210)
}

Speaking from the perspective of someone who teaches Irish Literature outside of Ireland to non-Irish students, this effort to 'literalize the imprint of Joyce on Irish culture' seems to extend beyond the tourist attractions and to have been often replicated by the publishing industry internationally, for instance. What do you see as a good approach to teaching Joyce to undergraduate students? How can those readers look away from their familiar Joyce?

\section{JOHN BRANNIGAN}

The essay you quote was written a long time ago, but if I recall, what I was trying to do in that essay was to examine how writers in the middle of the twentieth century were beginning to grapple with the process of Joyce the writer becoming Joyce the cultural icon. Perhaps in similar ways to the last question about how politicians quote from poets, there is an inevitable decontextualization of the writing which happens in that process. We forget how to read the work, and we begin instead 
to read the legend. There are so many preconceptions that we bring to the work of Joyce, and mostly in my own students I see as a result that Joyce becomes a source of fear. I've heard students say that they are saving reading Ulysses until they finish their degree, so that they might understand it. The best way to get beyond the aura which surrounds Joyce as a cultural icon, and his writings as works of genius, is to read the work. The mid-century writers I quoted in that essay set out to pull Joyce back down to earth - Brendan Behan described Ulysses as a 'gag book', a good source of jokes, while Flann O'Brien depicted Joyce as a pornographer. Both were attempting to rescue Joyce from the emerging industry of Joyce criticism, and to remind readers that Joyce was a writer whose works were worth reading rather than venerating. This is also the argument that Declan Kiberd made in his book, Ulysses and Us, that Joyce wrote the book as a celebration of the extraordinariness of ordinary people, and meant it to be read by those ordinary people.

\section{PALIMPSESTO}

5) In 'Intermodernism and the Middlebrow in Irish Writing' (2020), you observe that 'it could be argued that after 1922, the fledgling state, keen to dampen the radical energies of the revolutionary period and to safeguard a national culture, fostered and protected specifically middlebrow tendencies' (p. 105). Interestingly, however, the section about book clubs highlights that it was not just the Catholic Clubs that favoured 'the middlebrow', but the ones organised by the left in response as well:

\footnotetext{
Common to all book clubs, however, was the commitment, although hardly stated as such, to publish books which were neither esoteric nor trash. They could cater for particular religious or political affiliations, but the book clubs avoided the 'high' modernism of writers such as Joyce, Faulkner, Eliot and Woolf, even more stringently than they avoided the 'low' appeal of Westerns and murder mysteries. In this sense, they were inseparable from the reaction against modernism and aestheticism, and the turn towards an understanding of literature as a common good, accessible to what the Book-of-the-Month Club had called 'the average intelligent reader'. ( $\mathrm{p}$. 108-109)
}

With the rise of social media, book clubs of all orientations have become popular as small groups. Their reading choices vary according to the organisers and members. Some of those clubs are sponsored by celebrities in association with publishing houses, however. Whenever a book gets chosen, it becomes a bestseller. The question 
around the filtering behaviour behind the choice for the 'middlebrow' stands relevant when we think of the relationship between publishing, monetised influence, and social media. What do you make of the power dynamics behind readership formations in a contemporary context? Do you think film and streaming-service adaptations might change the reading public's relationship to those books?

\section{JOHN BRANNIGAN}

I must confess that I don't know very much about social media and celebrity book clubs, but in some ways I think there must be a kind of continuity with how book clubs have long functioned, which is, in part benign, to provide aspiring readers with a way of navigating the huge number of books published, and in part, and less innocently, to regulate reading habits in relation to a hegemonic set of social codes and conventions. Celebrity endorsement in many ways works in the same way as Catholic book clubs, or Left book clubs, of the past, which is as a kind of guarantee of a certain kind of 'middlebrow' taste, which is relatively safe and unthreatening. At their best, I suppose such clubs promise a community of readers, and enable readers to feel that they are sharing experiences with others, but as a cultural critic, it is difficult not to also feel that such clubs are prescribing particular forms of social and cultural community while denying or marginalising others. Those power dynamics have always been a part of the book club culture. One could say that in the past the book clubs were much more dependent upon centralised organisation, and a kind of official approval, whereas social media enables the proliferation of many more, specialised and potentially even subversive book clubs. But equally, as you suggest, contemporary book clubs are perhaps even more vulnerable to co-option by corporatist interests.

\section{PALIMPSESTO}

6) In 'Intermodernism and the Middlebrow in Irish Writing' (2020), you cite Faye Hammill's argument that 'to focus on the middlebrow is to remind ourselves that "tastes are constantly being re-evaluated and hierarchies reorganized" (p. 116). Which twentieth-century Irish writers would you say are being re-evaluated by the reading public or by academia?

\section{JOHN BRANNIGAN}


Over the last ten years or so, I think the work that has been done on Irish writers such as Sheila Wingfield, Blanaid Salkeld, Rhoda Coghill, and especially on Kate O'Brien has really highlighted the degree to which significant writing by women has been forgotten or marginalised. The special issue of the Irish University Review ${ }^{8}$ devoted to O'Brien's work in 2018, along with the opening exhibition on her work at the Museum of Literature Ireland, were two examples of a kind of re-focusing of attention on her importance and her legacy. That re-evaluation of writers from the past can come in various forms - such as a publisher deciding to re-publish forgotten work, as Tramp Press has done with Dorothy Macardle's novels, or a surge of interest among readers in a particular genre. There has been a rediscovery of Irish science fiction, for example, which has highlighted a fairly continuous if less celebrated tradition of science fiction writing throughout the twentieth century. I think the recent popularity of Irish crime fiction may see something similar in recovering twentieth century crime writers. To go back to your earlier questions about Brexit and the pandemic, and the potential for such events to trigger change, I think one of the ways we can see such change is precisely in a re-evaluation and re-ordering of literary tastes. In this sense, literary and cultural criticism has an important role to play in recovering the marginalised voices from the past, and making them available to emerging voices and readerships today.

\section{Works Cited}

BETIM, Felipe. Brasil registra recorde de 4.195 novas mortes por covid-19 e prenuncia abril "trágico". EL PAÍS Brasil. 6 Apr. 2021. Available at: https://brasil.elpais.com/brasil/2021-04-06/brasil-registra-recorde-de-4195-novasmortes-por-covid-19-e-prenuncia-abril-tragico.html Accessed on: 17 Apr. 2021.

BIDEN, Joseph. Remarks by the Vice President at a Breakfast with the American Chamber of Commerce in Beijing and the U.S.-China Business Council. The White House. 5 Dec. 2013. Available at: https://obamawhitehouse.archives.gov/the-pressoffice/2013/12/05/remarks-vice-president-breakfast-american-chamber-commercebeijing-and-u Accessed on 24 Feb. 2021.

BRANNIGAN, John. Archipelagic Modernism: Literature in the Irish and British Isles, 1890-1970. Edinburgh University Press. Kindle Edition. 
BRANNIGAN, John. Seán O'Casey and Brendan Behan: Aesthetics, Democracy and the Voice of Labour In: PIERSE, Michael (Ed). A History of Irish Working-Class Writing. Cambridge: CUP, 2017. p. 289-302.

BRANNIGAN, John. Intermodernism and the Middlebrow in Irish Writing. In: PATTEN, Eve (Ed.). Irish Literature in Transition, 1940-1980. Cambridge: CUP, 2020. p. 103-118.

BRANNIGAN, John; WARD, Geoff; WOLFREYS, Julian. (Eds.) Re: Joyce: Text. Culture. Politics. New York: St. Martin's Press, 1998.

BEHR, Rafael. Boris Johnson's Brexit has always been a swindle. Now Ireland will pay the price. The Guardian. 15 Sep. 2020. Available at:

https://www.theguardian.com/commentisfree/2020/sep/15/boris-johnson-brexitswindle-ireland-eurosceptic-good-friday-agreement Accessed on 24 Feb. 2021.

DOLAN, Naoise. Exciting Times. London: Weidenfeld \& Nicolson, 2020.

MCKENZIE, Lewis; MORRIS, Sophie. British government has 'unlimited disregard' for Good Friday Agreement. The Irish News. 02 Dec. 2020. Available at:

https://www.irishnews.com/news/brexit/2020/12/02/news/british-government-hasunlimited-disregard-for-good-friday-agreement-2148870/ Accessed on 24 Feb. 2021.

O'CARROLL, Lisa. Huge surge in Britons applying for non-UK passports. The Guardian. 30 Jan. 2020. Available at: https://www.theguardian.com/politics/2020/jan/30/brexit-730000-britons-acquirednon-uk-eu-irish-passports-since-2016. Accessed on 24 Feb. 2021.

PATTEN, Eve. Introduction. In: PATTEN, Eve (Ed.). Irish Literature in Transition, 1940-1980. Cambridge: CUP, 2020. p. 1-24. 


\title{
Pensando em termos arquipelágicos: uma entrevista com John Brannigan
}

\author{
John Brannigan ${ }^{\mathrm{v}}$ \\ Entrevistadoras: \\ Marcela Santos Brigida ${ }^{\mathrm{vi}}$ \\ Thayane Verçosa ${ }^{\text {vii }}$ \\ Gabriela Ribeiro Nunes ${ }^{\text {viii }}$
}

John Brannigan, Professor da Faculdade de Inglês, Drama e Cinema da University College Dublin, é autor de livros como New Historicism and Cultural Materialism (1998), Race in Modern Irish Literature and Culture (2009) e Archipelagic Modernism: Literature in the Irish and British Isles, 1890-1970 (2014), e é um nome ilustre em sua área. Ele também é uma voz que estou feliz por ter a oportunidade de apresentar a muitos de meus pares nesta entrevista. Por ser uma publicação para a qual jovens pesquisadores têm a oportunidade de submeter seus trabalhos pela primeira vez, além de ser editada por alunos de pós-graduação, a Palimpsesto é, afinal, uma revista que circula amplamente entre nossos colegas. À

\footnotetext{
v John Brannigan é Professor da Faculdade de Inglês, Drama e Cinema da University College Dublin. Ele possui interesse de pesquisa nas literaturas do século XX da Irlanda, Inglaterra, Escócia e País de Gales, com foco particular nas relações entre literatura e identidades sociais e culturais. Seu primeiro livro, New Historicism and Cultural Materialism (1998), foi um estudo das principais metodologias historicistas da crítica literária do final do século XX. Desde então, publicou dois livros sobre a história do pós-guerra da literatura inglesa $(2002,2003)$, livros impactantes sobre os autores de classe trabalhadora Brendan Behan (2002) e Pat Barker (2005), e o primeiro livro a investigar a literatura e a cultura irlandesa do século XX usando teorias raciais críticas, Race in Modern Irish Literature and Culture (2009). Seu livro mais recente, Archipelagic Modernism: Literature in the Irish and British Isles, 1890-1970 (2014), explora novas maneiras de compreender a relação entre literatura, lugar e ambiente na escrita irlandesa e britânica do século XX. Ele foi editor do periódico internacional com avaliação pelos pares, Irish University Review, de 2010 a 2016.
}

${ }^{\text {vi }}$ Doutoranda em Literaturas de Língua Inglesa na Universidade do Estado do Rio de Janeiro (UERJ). Bolsista CNPq. Criadora de conteúdo digital no projeto Literatura Inglesa Brasil: https://instagram.com/literaturainglesabr | https://orcid.org/0000-0002-0951-1603 | marcela@literaturainglesa.com.br

vii Doutoranda em Letras pela Universidade do Estado do Rio de Janeiro (UERJ). Bolsista CAPES. thayanevercosa@hotmail.com

viii Doutoranda em Teoria da Literatura/Literatura Comparada pela Universidade do Estado do Rio de Janeiro (UERJ). j15c17g11@ @hotmail.com 
medida que o tempo que compartilhamos como editoras gerais de Palimpsesto chega ao fim com a publicação deste número, acredito Gabriela Ribeiro Nunes e eu gostaríamos de deixar a revista com uma nota que lembre a todos nós que é possível produzir e incentivar um trabalho acadêmico sério em uma atmosfera acolhedora e calorosa. O Professor Brannigan foi muito gentil em aceitar nosso convite para uma entrevista por e-mail. Como pesquisadora da Literatura Irlandesa, é uma alegria tematizá-la em uma entrevista neste periódico pela primeira vez desde sua primeira publicação. É uma demonstração dos muitos caminhos que ainda podemos percorrer aqui como alunos em diálogo com pesquisadores experientes cujo trabalho admiramos. Este, eu acredito, é um motivo para comemorar.

$\mathrm{Na}$ introdução a Archipelagic Modernism: Literature in the Irish and British Isles, 1890-1970 (2015), Brannigan faz referência a After London (1885), um romance em que Richard Jefferies "imaginou um futuro em que a geografia da Inglaterra foi dramaticamente alterada por uma catástrofe ambiental” na qual "o aumento do nível do mar e os efeitos de estruturas criadas pelo homem nos cursos de água se combinam para inundar partes do centro e do sul da Inglaterra" (BRANNIGAN, 2015, Loc 82). O autor, Brannigan observa, não adiciona um tom utópico à "Inglaterra arquipelágica que toma o lugar da sua antecessora afogada" (BRANNIGAN, 2015, Loc 99). Aqui, não há uma "sociedade ideal surgindo para florescer na esteira da velha, apenas um passado anárquico e violento bastante familiar voltando para assombrar um povo inglês que agora só podia se lembrar vagamente de ter estado no centro de um império global, e do motor do progresso industrial” (BRANNIGAN, 2015, Loc 105). Para William Morris, entretanto, "After London sugeriu a possibilidade de recomeçar, de redefinir os termos sobre os quais uma sociedade inglesa poderia ser fundada e de como ela poderia se relacionar com seus vizinhos." (BRANNIGAN, 2015, Loc 105). Ao longo do texto, Brannigan apresenta ao leitor a abordagem do livro de análise arquipelágica de identidades políticas - bem como das relações entre os países que ocupam as ilhas do arquipélago irlandês e britânico. Eu diria que o Archipelagic Modernism é uma leitura necessária para qualquer pessoa interessada não apenas na literatura modernista produzida na Irlanda, Escócia, País de Gales e Inglaterra, mas também para aqueles que veem a necessidade de reavaliar as dinâmicas e tensões políticas que permeiam essas literaturas também. 
Um ano após o início de uma pandemia que impactou a maneira como a maioria - senão todos - nós vivemos, além de causar traumas coletivos insondáveis (enquanto escrevo isto, uma notificação me alerta para o fato de que hoje o Brasil registrou 4.195 mortes relacionadas ao Covid-1999), muitos de nós recorremos à literatura em busca de formas de lidar com a crise. Em nossa entrevista, o professor Brannigan apontou que "toda pandemia causou ou ameaçou causar mudanças na sociedade e na cultura e, portanto, toda pandemia precisa da imaginação de alternativas". Ao compartilhar orgulhosamente este artigo com os leitores de Palimpsesto, convido cada um de vocês a fazer exatamente isso. Espero que, daqui a um ano, possamos nos encontrar de novo com segurança e, de alguma forma, olhar para o que aconteceu com um olhar crítico, mas com uma perspectiva já diferente. Estou profundamente grata ao Professor John Brannigan por aceitar nosso convite e por compartilhar seu brilhante trabalho e palavras conosco.

Marcela Santos Brigida

\section{PALIMPSESTO}

1) Discutindo a "penosa distância entre a cultura irlandesa e os principais eventos internacionais e políticos do período de guerra" (p. 4) na introdução de Irish Literature in Transition, 1940-1980 (2020), Eve Patten argumenta que, "de uma perspectiva literária, a Irlanda de meados do século XX muitas vezes confunde a retórica do isolamento e registra, em vez disso, o impacto da proximidade e da conexão, um tema que se estende até as décadas do pós-guerra e por diversas comunidades culturais" (2020, p. 5). Durante as negociações do Brexit, os primeiros-ministros britânicos encarregados das negociações com a União Europeia foram frequentemente acusados de negligenciar a Irlanda e o Acordo de Belfast (MCKENZIE, MORRIS, 2020; BEHR, 2020). Ironicamente, as limitações impostas pelo Brexit aos próprios britânicos quando na Europa levaram a um aumento nas solicitações de vistos irlandeses por cidadãos do Reino Unido (O'CARROLL, 2020). Neste sentido, essa reivindicação prática de uma identidade irlandesa pode assumir vários significados. Esta tensão já aparece na ficção irlandesa contemporânea. Em Exciting Times (2020), de Naoise Dolan, um banqueiro inglês chamado Ralph havia "votado pelo Brexit para ter fronteiras mais estreitas e estava solicitando um passaporte irlandês para evitar ser parado nelas" (p. 31). Você acredita que podemos esperar ver 
mais desse paradoxo entre isolamento político e uma instrumentalização complicada da identidade na ficção irlandesa?

\section{JOHN BRANNIGAN}

Esta é uma questão muito interessante e produtiva, especialmente a conexão que você faz com o período de meados do século. O isolamento político da Irlanda na metade do século XX foi em parte uma reação contra o fato de fazer parte do Império Britânico. A neutralidade durante a Segunda Guerra Mundial foi uma forma muito importante, embora controversa, de a Irlanda continuar a afirmar sua independência e autossuficiência. Para alguns escritores que eram críticos ou ambivalentes em relação à neutralidade irlandesa, como Louis MacNeice ou Dorothy Macardle, a luta contra o nazismo era um apelo por uma aliança humanitária internacionalista e, nesse contexto, a neutralidade irlandesa parecia uma espécie de retirada de responsabilidade moral. MacNeice se referiu a isso em seu poema sobre a neutralidade irlandesa como "A ilha neutra no coração do homem"10 e atribuiu essa frieza a uma fantasia de insularidade, de que as ilhas podem se isolar do mundo. Por mais que a Irlanda de meados do século possa ser vista como politicamente isolada, entretanto, acho que Eve Patten está certa em argumentar que a literatura do período conta uma história diferente. Se pensarmos em Finnegans Wake, publicado em 1939, Beckett na França durante a guerra, o trabalho de Kate O'Brien e Dorothy Macardle, e no rescaldo da guerra, a influência contínua da literatura europeia pode ser vista na revista Envoy, na amizade de Brendan Behan com Camus em Paris e nas reuniões sociais de Sean O'Faolain nas quais ele discutia a literatura europeia com jovens escritores. Essa Eurofilia cultural era evidente na literatura irlandesa, talvez antes de se tornar evidente politicamente. A Irlanda aderiu à Comunidade Europeia ao mesmo tempo que a GrãBretanha, em 1972, e de muitas maneiras ajudou a normalizar e estabilizar as relações políticas entre os dois países, e certamente deve ser considerada como a base sobre a qual o Acordo de Belfast foi firmado em 1998. O Brexit é uma espécie de quebracabeça para muitos irlandeses, tenho certeza, mas na Irlanda estamos acostumados a ver a evidência dos benefícios econômicos e culturais da adesão à União Europeia. Todas as novas estradas e comodidades turísticas incluem uma placa com a bandeira da UE, denotando a contribuição financeira da UE para o projeto. É mais difícil ver evidências de tais benefícios no próspero sul da Inglaterra, e foi certamente 
uma visão muito anglocêntrica do mundo que informou e alimentou o Brexit. Uma implicação de sua pergunta, eu acho, é que o Brexit inverteu a posição da Irlanda e da Grã-Bretanha da Segunda Guerra Mundial, com a Grã-Bretanha agora escolhendo se isolar da Europa, cultural e politicamente. O problema com isso, de uma perspectiva cultural irlandesa, é que sabemos pela nossa história que isso não é desejável nem possível. A retórica do Brexit tende sempre a simplificar relações que são histórica e inevitavelmente complexas, nunca mais do que com as relações angloirlandesas. Portanto, estamos vendo esses fenômenos aparentemente estranhos emergindo, de sindicalistas comprometidos em busca de passaportes irlandeses, de um Brexit que deveria ser sobre a soberania britânica enfraquecendo o comércio e o movimento dentro do Reino Unido, e de comunidades pesqueiras britânicas supostamente um dos fatores de motivação para Brexit - sendo as primeiras a sofrer suas consequências. Em meu próprio trabalho, tendi a ver essas relações em termos arquipelágicos, que as ilhas e regiões da Irlanda e da Grã-Bretanha estão culturalmente interligadas de maneiras muito mais complexas do que as estruturas nacionais poderiam sugerir. O Brexit foi fundado, como eu disse, em uma visão fortemente anglocêntrica, e é em relação a essa visão que eu acho que veremos a literatura do arquipélago irlandês e britânico entrando em atrito e reagindo.

\section{PALIMPSESTO}

2) Você abre o seu capítulo sobre Seán O'Casey e Brendan Behan em A History of Irish Working-Class Writing (2017), citando o argumento de Thomas Docherty em Aesthetic Democracy de que "estética e democracia estão essencialmente preocupadas com a mesma questão fundamental: 'como as mudanças acontecem e como passamos de um estado de coisas para outro?"' (BRANNIGAN, 2017, p. 289). Além disso, você também afirma que "a arte é potencialmente alterada por cada obra de arte; a democracia é potencialmente alterada por toda ação democrática" (BRANNIGAN, 2017, p. 289). Aceitando que "tais atos de transformação são 'episódicos e raros', e que são 'baseados na esperança e na expectativa e não em princípios" (BRANNIGAN, 2017, p. 289), é inegável que a pandemia tem sido uma fonte devastadora de mudanças em uma escala mundial que possui mais ramificações do que as que já identificamos. No entanto, você acredita que a consciência política e social que ela despertou em muitos - em relação a 
questões que se estendem desde saúde a financiamento para as artes - terá um efeito duradouro?

\section{JOHN BRANNIGAN}

Toda pandemia causou ou ameaçou causar mudanças na sociedade e na cultura e, portanto, toda pandemia precisa da imaginação de alternativas, geralmente, é claro, alternativas distópicas. As pandemias exigem que consideremos possibilidades ficcionais. As crises climáticas fazem o mesmo - como será o mundo com o aumento do nível do mar, ou com a poluição permanente, ou com a extinção de espécieschave? E, é claro, pode-se dizer que temos imaginado as mudanças sociais ocasionadas pelas pandemias muito antes de nossa atual pandemia. Ao longo dessa pandemia, vários políticos falaram em seguir a ciência, mas, de certa forma, a ciência também tem seguido uma narrativa cultural. Nos livros, nos filmes e na arte já nos acostumamos com a narrativa e o imaginário de máscaras, distanciamento social, hospitais e necrotérios sobrecarregados, o esvaziamento das ruas, o pânico das compras em supermercados, a busca por uma vacina ou cura, e assim por diante. No início da pandemia do coronavírus, por exemplo, muitas pessoas começaram a ler $A$ Peste, de Camus, ou Amor nos Tempos do Cólera ${ }^{11}$, ou The Andromeda Strain ${ }^{12}$. Há muito tempo que imaginamos pandemias, nossa imaginação delas é uma manifestação de preocupação com o futuro e com a maneira como a narrativa de nossas formas contemporâneas de sociedade, cultura e economia se desenrola. A pandemia de gripe de 1918 também foi pré-imaginada em livros como The Scarlet Plague, de Jack London, e também marcou a literatura da época, em The Waste Land, de Eliot, e Mrs. Dalloway e To The Lighthouse, de Woolf, por exemplo. O impacto cultural, sem dúvida, foi imenso, e alguns argumentam que a Era do Jazz dos anos 1920 e início dos anos 1930 pode ser atribuída à reação a essa pandemia. Portanto, temos modelos culturais que podem nos ajudar a entender as pandemias e seus impactos. Isso não quer dizer, entretanto, que o impacto da pandemia em si não foi chocante e tem potencial para causar mudanças. É possível que a consciência mais ampla das desigualdades sociais, do subfinanciamento da saúde, do bem-estar social, da educação e das artes, e do papel do Estado na biopolítica, possa impulsionar a demanda por mudanças. Nos piores pontos da pandemia, reconhecemos que as pessoas que passamos a conhecer como "trabalhadores essenciais" também são os 
trabalhadores com salários mais baixos. Houve um momento semelhante, é claro, durante a crise financeira de 2008 , quando as pessoas começaram a ver isso como uma crise para o capitalismo. Fredric Jameson nos alertou para as maneiras pelas quais imaginar o fim do mundo - que é certamente o modo como muitas ficções pandêmicas se desenrolam - pode muitas vezes ser um substituto para imaginar o fim do capitalismo. Mas o que ouvimos agora com mais frequência com o lançamento dos programas de vacinação é o clamor por um retorno à normalidade, e seria difícil prever mudanças positivas duradouras na política e na sociedade nesse contexto.

\section{PALIMPSESTO}

3) Ao longo do ciclo eleitoral de 2020 nos Estados Unidos, Joe Biden frequentemente citou versos de The Cure at Troy (1991), de Seamus Heaney. Ao longo de sua carreira política, ele também citou - e se declarou fã de - Yeats. Em um comentário de 2013 que se tornou popular desde sua posse, Biden disse: "Meus colegas sempre brincam comigo por eu citar poetas irlandeses o tempo todo. Acham que faço isso porque sou irlandês, mas eu faço porque são os melhores poetas" (BIDEN, 2013). Embora a maioria tenha visto essa conexão com a literatura irlandesa como uma influência positiva na política estadunidense, alguns brincaram no Twitter com o fato de as referências de Biden parecerem incluir apenas homens ${ }^{13}$. Que poetas mulheres irlandesas você recomendaria para expandir os hábitos de leitura das pessoas interessadas na poesia irlandesa?

\section{JOHN BRANNIGAN}

Por onde começar? Em primeiro lugar, devo ser sincero e dizer que, quando ouço Biden citar Heaney e Yeats, sinto um pequeno brilho de prazer. É um grande alívio depois de quatro anos de tweets incompreensíveis e ofensivos. Mas, é claro, Biden não é o primeiro presidente a fazê-lo, e Obama e Clinton costumavam citar os mesmos poetas, principalmente em relação ao processo de paz na Irlanda do Norte. Para ser mais cético, é claro, quando os políticos citam poesia, geralmente há razões políticas muito calculadas para fazê-lo, isso os faz parecer mais letrados e educados, atrai certos eleitores ou eleva a retórica política de questões mundanas de gestão econômica para o reino das aspirações sociais e culturais. Geraldine Higgins

escreveu um artigo ótimo sobre isso ${ }^{14}$, especialmente sobre como os políticos citaram 
Yeats durante o processo de paz, e ela argumentou que Yeats havia se tornado o poeta favorito para ser citado pelos políticos. Claro, há muitas poetas irlandesas mulheres que são tão eminentes, tão lidas e tão citáveis quanto Yeats ou Heaney Heaney - Eavan Boland, Sinead Morrissey, Nuala Ní Dhomhnaill, Eiléan Ní Chuilleanáin, Paula Meehan, Moya Cannon, Mary O’Malley, Medbh McGuckian, Vona Groarke, apenas para começar. O fato de geralmente não serem citadas em discursos políticos, pelo menos não com a mesma frequência com que encontramos Yeats e Heaney, é uma indicação dos termos estreitos em que essa bênção política da poesia ocorre. Se eu fosse arriscar um palpite sobre as razões para a natureza estreita e masculina desse cânone de poetas citáveis, acredito que esteja relacionado com uma suposição oculta de que os poetas homens são vozes públicas, que falam a consciência da tribo, enquanto as mulheres poetas são consideradas vozes privadas e individuais. E assim, esses poetas são compreendidos como portadores de um tipo de autoridade cultural que pode ser emprestada e gasta no domínio público da política. Talvez outra razão seja que Yeats e Heaney têm, com ou sem razão, muitas vezes sido associados a uma narrativa nacional, com uma lealdade singular, e aqui eu pensaria no argumento de Edna Longley de The Living Stream ${ }^{15}$ de que existe uma tendência feminista alternativa de habitar relações e lealdades múltiplas simultaneamente, e de conectá-las.

\section{PALIMPSESTO}

4) No prefácio de Re: Joyce: Text. Culture. Politics (1998), você, Julian Wolfreys e Geoff Ward argumentam que é adequado que "a 'Joyce tour' de inscrições de bronze na calçada agora faça parte da paisagem física da cidade, como se literalizasse a marca de Joyce na cultura irlandesa" e que "essas marcas são principalmente atrações turísticas, projetadas de dentro para fora da nação" (p. xiv-xv). Isso é, vocês explicam, "verdadeiro no que diz respeito à complexa relação entre Joyce e a cultura irlandesa" (p. xiv). Em seu capítulo nesse mesmo livro, "Joyce Will Attend: The Joyce Tour of Postwar Literature", você argumenta que:

\footnotetext{
Joyce prolifera em espectros por toda a literatura do pós-guerra, mas não, entretanto, para preservar um Joyce essencial, um Joyce familiar. Em vez disso, os espectros de Joyce comparecem hoje a fim de prestar homenagem ao Outro ausente, ao não-Joyce e, mais importante, para nos convidar constantemente a deslocar a realização de conhecer Joyce. Joyce é o texto involuntário, o Outro espectral surpreendente, circulando na literatura do
} 
pós-guerra. Joyce comparecerá, mas sempre já como Outro, como diferença. (p. 210)

Falando a partir da perspectiva de alguém que leciona Literatura Irlandesa fora da Irlanda para estudantes não-irlandeses, este esforço para "literalizar a marca de Joyce na cultura irlandesa" parece se estender para além das atrações turísticas e ter sido frequentemente replicado pela indústria editorial internacional, por exemplo. O que você considera como uma boa abordagem para lecionar sobre Joyce a alunos na graduação? Como esses leitores podem desviar o olhar de seu Joyce familiar?

\section{JOHN BRANNIGAN}

O ensaio que você cita foi escrito há muito tempo, mas, se bem me lembro, o que eu estava tentando fazer naquele ensaio era examinar como escritores em meados do século XX estavam começando a lidar com o processo de Joyce, o escritor, se tornando Joyce, o ícone cultural. Talvez de maneira semelhante à última pergunta sobre como os políticos citam os poetas, há uma inevitável descontextualização da escrita que acontece nesse processo. Esquecemos como ler a obra e, em vez disso, começamos a ler a lenda. Há tantos preconceitos que trazemos para a obra de Joyce, e principalmente em meus próprios alunos, vejo como resultado que Joyce se torna uma fonte de medo. Já ouvi alunos dizerem que estão guardando a leitura de Ulysses até terminar a graduação, para que possam entendê-lo. A melhor maneira de superar a aura que cerca Joyce como ícone cultural e seus escritos como obras de gênio é ler a obra. Os escritores de meados do século que citei naquele ensaio tentaram trazer Joyce de volta à terra - Brendan Behan descreveu Ulysses como um "gag book", uma boa fonte de piadas, enquanto Flann O'Brien descreveu Joyce como um pornógrafo. Ambos estavam tentando resgatar Joyce da indústria emergente da crítica de Joyce e lembrar aos leitores que Joyce era um escritor cujas obras valiam a pena ler em vez de venerar. Este é também o argumento que Declan Kiberd apresentou em seu livro, Ulysses and Us, de que Joyce escreveu o livro como uma celebração da extraordinária qualidade das pessoas comuns e pretendia que ele fosse lido por essas pessoas comuns.

\section{PALIMPSESTO}


5) Em "Intermodernism and the Middlebrow in Irish Writing", você observa que "poderia ser argumentado que, após 1922, o estado incipiente, ansioso para amortecer as energias radicais do período revolucionário e para salvaguardar uma cultura nacional, fomentada e protegida especificamente tendências middlebrow ${ }^{16}$ " (p. 105). Curiosamente, no entanto, a seção sobre os clubes do livro destaca que não foram apenas os clubes católicos que favoreceram a "middlebrow", mas também aqueles organizados pela esquerda em resposta:

Comum a todos os clubes do livro, entretanto, era o compromisso, embora
dificilmente declarado como tal, de publicar livros que não fossem
esotéricos, nem lixo. Eles podiam atender
a determinadas afiliações religiosas ou políticas, mas os clubes do livro
evitavam o "alto" modernismo de escritores como Joyce, Faulkner, Eliot e
Woolf, ainda mais rigorosamente do que evitavam o apelo "baixo" dos
faroestes e livros de mistérios e assassinatos. Nesse sentido, eram
indissociáveis da reação contra o modernismo e do esteticismo, e da virada
para uma compreensão da literatura como um bem comum, acessível a
quem o Book-of-the-Month Club chamou de "o leitor inteligente
mediano". (p. 108-109)

Com o surgimento das redes sociais, clubes do livro de todas as orientações se tornaram populares como pequenos grupos. Suas escolhas de leitura variam de acordo com os organizadores e membros. No entanto, alguns desses clubes são patrocinados por celebridades em associação com editoras. Sempre que um livro é escolhido, ele se torna um best-seller. A questão em torno do comportamento de filtragem por trás da escolha da "middlebrow" permanece relevante quando pensamos na relação entre publicação, influência monetizada e mídias sociais. O que você acha da dinâmica de poder por trás da formação de leitores em um contexto contemporâneo? Você acredita que as adaptações de filmes e serviços de streaming podem mudar a relação do público leitor com esses livros?

\section{JOHN BRANNIGAN}

Devo confessar que não sei muito sobre redes sociais e clubes do livro de celebridades, mas de certa forma acho que deve haver uma espécie de continuidade na forma como os clubes do livro têm funcionado há muito tempo, que é em parte benigna, fornecendo aspirantes a leitores com uma forma de navegar pela grande quantidade de livros publicados e, em parte, e menos inocentemente, regulando os hábitos de leitura em relação a um conjunto hegemônico de códigos e convenções sociais. $\mathrm{O}$ endosso de celebridades de muitas maneiras funciona da mesma forma que os clubes do livro católicos, ou clubes do livro de esquerda, do passado, o que é uma espécie de garantia de um certo tipo de gosto "middlebrow", que é relativamente 
seguro e não ameaçador. Na melhor das hipóteses, suponho que esses clubes prometam uma comunidade de leitores e permitam que os leitores sintam que estão compartilhando experiências com outras pessoas, mas, como um crítico cultural, é difícil não sentir também que esses clubes estão prescrevendo formas específicas de comunidade cultural enquanto negam ou marginalizam outras. Essas dinâmicas de poder sempre fizeram parte da cultura do clube do livro. Pode-se dizer que, no passado, os clubes do livro dependiam muito mais de uma organização centralizada e de uma espécie de aprovação oficial, ao passo que as redes sociais permitem a proliferação de muitos outros clubes do livro especializados e potencialmente subversivos. Mas, da mesma forma, como você sugere, os clubes do livro contemporâneos talvez sejam ainda mais vulneráveis à cooptação por interesses corporativos.

\section{PALIMPSESTO}

6) Em "Intermodernism and the Middlebrow in Irish Writing" (2020), você cita o argumento de Faye Hammill de que "focar na middlebrow é nos lembrar que 'gostos estão constantemente sendo reavaliados e hierarquias reorganizadas"' (p. 116). Quais escritores irlandeses do século XX você diria que estão sendo reavaliados pelo público leitor ou pela academia?

\section{JOHN BRANNIGAN}

Nos últimos dez anos ou algo assim, acho que o trabalho que foi feito sobre escritores irlandeses como Sheila Wingfield, Blanaid Salkeld, Rhoda Coghill e, especialmente, sobre Kate O’Brien realmente destacou o grau em que a escrita significativa de mulheres tem sido esquecida ou marginalizada. A edição especial da Irish University Review dedicada ao trabalho de O'Brien em $2018^{17}$, juntamente com a exposição de abertura de seu trabalho no Museum of Literature Ireland, foram dois exemplos de uma espécie de reorientação da atenção para sua importância e seu legado. Essa reavaliação de escritores do passado pode vir de várias formas - como uma editora decidindo republicar uma obra esquecida, como a Tramp Press fez com os romances de Dorothy Macardle, ou uma onda de interesse entre os leitores por um gênero específico. Houve uma redescoberta da ficção científica irlandesa, por 
exemplo, que destacou uma tradição bastante contínua, embora menos celebrada, de escrita de ficção científica ao longo do século XX. Acho que a popularidade recente da ficção policial irlandesa pode produzir algo semelhante na recuperação de escritores de ficção policial do século XX. Voltando às suas perguntas anteriores sobre o Brexit e a pandemia, e o potencial de tais eventos desencadearem mudanças, acho que uma das maneiras pelas quais podemos ver essa mudança é precisamente em uma reavaliação e reordenação dos gostos literários. Nesse sentido, a crítica literária e cultural tem um papel importante a desempenhar na recuperação das vozes marginalizadas do passado, tornando-as disponíveis para vozes e leitores emergentes hoje.

\section{Referências}

BETIM, Felipe. Brasil registra recorde de 4.195 novas mortes por covid-19 e prenuncia abril "trágico". EL PAÍS Brasil. 6 Abr. 2021. Disponível em: https://brasil.elpais.com/brasil/2021-04-06/brasil-registra-recorde-de-4195-novasmortes-por-covid-19-e-prenuncia-abril-tragico.html Acesso em: 17 Abr. 2021.

BIDEN, Joseph. Remarks by the Vice President at a Breakfast with the American Chamber of Commerce in Beijing and the U.S.-China Business Council. The White House. 5 Dez. 2013. Disponível em: https://obamawhitehouse.archives.gov/the-pressoffice/2013/12/05/remarks-vice-president-breakfast-american-chamber-commercebeijing-and-u Acesso em 24 Fev. 2021.

BRANNIGAN, John. Archipelagic Modernism: Literature in the Irish and British Isles, 1890-1970. Edinburgh University Press. Kindle Edition.

BRANNIGAN, John. Seán O'Casey and Brendan Behan: Aesthetics, Democracy and the Voice of Labour In: PIERSE, Michael (Ed). A History of Irish Working-Class Writing. Cambridge: CUP, 2017. p. 289-302.

BRANNIGAN, John. Intermodernism and the Middlebrow in Irish Writing. In: PATTEN, Eve (Ed.). Irish Literature in Transition, 1940-1980. Cambridge: CUP, 2020. p. 103-118.

BRANNIGAN, John; WARD, Geoff; WOLFREYS, Julian. (Eds.) Re: Joyce: Text. Culture. Politics. New York: St. Martin's Press, 1998.

BEHR, Rafael. Boris Johnson's Brexit has always been a swindle. Now Ireland will pay the price. The Guardian. 15 Set. 2020. Disponível em: 
https://www.theguardian.com/commentisfree/2020/sep/15/boris-johnson-brexitswindle-ireland-eurosceptic-good-friday-agreement Acesso em: 24 Fev. 2021.

DOLAN, Naoise. Exciting Times. London: Weidenfeld \& Nicolson, 2020.

MCKENZIE, Lewis; MORRIS, Sophie. British government has 'unlimited disregard' for Good Friday Agreement. The Irish News. 02 Dez. 2020. Disponível em: https://www.irishnews.com/news/brexit/2020/12/02/news/british-government-hasunlimited-disregard-for-good-friday-agreement-2148870/ Acesso em: 24 Fev. 2021.

O'CARROLL, Lisa. Huge surge in Britons applying for non-UK passports. The Guardian. 30 Jan. 2020. Disponível em:

https://www.theguardian.com/politics/2020/jan/30/brexit-730000-britons-acquirednon-uk-eu-irish-passports-since-2016. Acesso em: 24 Fev. 2021.

PATTEN, Eve. Introduction. In: PATTEN, Eve (Ed.). Irish Literature in Transition, 1940-1980. Cambridge: CUP, 2020. p. 1-24.

\footnotetext{
${ }^{1}$ Those numbers were recorded on 6 April 2021 (BETIM, 2021).

${ }^{2}$ Editor's note: Brannigan is quoting from MacNeice's poem "Neutrality", originally published in 1942.

${ }^{3}$ Editor's note: novel by Gabriel García Márquez originally published in 1985.

${ }^{4}$ Novel by Michael Crichton originally published in 1969.

5 Tweet by Second Shelf Books: https://twitter.com/secondshelfbks/status/1351941265181597708

${ }^{6}$ HIGGINS, Geraldine. The Quotable Yeats: Modified in the Guts of the Living. South Carolina Review, Clemson, v. 32, n. 1, p. 184-92, 1999.

${ }^{7}$ LONGLEY, Edna. The Living Stream: Literature \& Revisionism in Ireland. Newcastle upon Tyne: Bloodaxe Books, 1994.

${ }^{8}$ Editor's note: Irish University's special issue devoted to Kate O'Brien's work (Volume 48, Issue 1) is available at: https://www.euppublishing.com/toc/iur/48/1.

${ }^{9} \mathrm{O}$ registro é de 6 de abril de 2021. (BETIM, 2021).

${ }^{10}$ Nota da editora: Brannigan faz referência ao poema "Neutrality", de 1942.

${ }^{11}$ Nota da editora: romance de Gabriel García Márquez publicado originalmente em 1985.

${ }^{12}$ Nota da editora: romance de Michael Crichton publicado originalmente em 1969.

13 Tweet da Second Shelf Books: https://twitter.com/secondshelfbks/status/1351941265181597708
} 
${ }^{14}$ HIGGINS, Geraldine. The Quotable Yeats: Modified in the Guts of the Living. South Carolina Review, Clemson, v. 32, n. 1, p. 184-92, 1999.

${ }^{15}$ Nota da editora: a coleção de ensaios The Living Stream: Literature \& Revisionism in Ireland foi publicada por Edna Longley em 1994 via Bloodaxe Books.

${ }^{16}$ Nota da editora: ao longo do texto em questão, Brannigan emprega o termo "middlebrow" para se referir a um setor do mercado editorial fomentado pelas formas de censura impulsionadas pelo contexto político descrito no recorte citado na pergunta. A "middlebrow" incluiria uma série de publicações populares e não-subversivas:

"O muito observado conservadorismo das instituições culturais irlandesas do período de meados do século - mais notoriamente o Abbey Theatre sob a direção de Ernest Blythe - direcionou um meiotermo seguro entre a cultura 'baixa' e a 'alta'. Isso ficou evidente não apenas para os escritores que tinham motivos para amaldiçoar a resultante 'Vitória da Mediocridade' (para citar a condenação fulminante de Patrick Kavanagh à cultura irlandesa de meados do século), mas também para escritores e artistas visitantes." (BRANNIGAN, 2020, p. 105-106).

${ }^{17}$ Nota da editora: O volume 48, n. 1 da Irish University Review, dedicado a Kate O'Brien, está disponível em: https://www.euppublishing.com/toc/iur/48/1. 